\title{
Influence of periostin-positive cell-specific KIf5 deletion on aortic thickening in DOCA-salt hypertensive mice
}

\author{
Hirofumi Zempo ${ }^{1}$, Jun-ichi Suzuki ${ }^{2}$, Masahito Ogawa ${ }^{3}$, Ryo Watanabe ${ }^{1}$, Katsuhito Fujiu ${ }^{4}$, Ichiro Manabe ${ }^{4}$, \\ Simon J Conway ${ }^{5}$, Yoshiaki Taniyama ${ }^{6}$, Ryuichi Morishita ${ }^{6}$, Yasunobu Hirata ${ }^{2}$, Mitsuaki Isobe $^{1}$ and \\ Ryozo $\mathrm{Nagai}^{7}$
}

Chronic hypertension causes vascular remodeling that is associated with an increase in periostin- (postn) positive cells, including fibroblasts and smooth muscle cells. Krüppel-like factor (KLF) 5, a transcription factor, is also observed in vascular remodeling; however, it is unknown what role KLF5 plays in postn-positive cells during vascular remodeling induced by deoxycorticosterone-

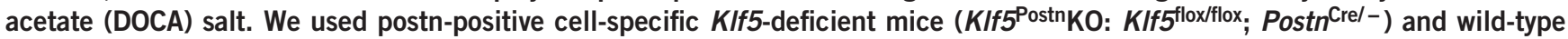
mice (WT: KIf5 flox/flox; Postn ${ }^{-l-}$ ). We implanted a DOCA pellet and provided drinking water containing $0.9 \% \mathrm{NaCl}$ for 8 weeks. The DOCA-salt treatment induced hypertension in both genotypes, as observed by increases in systolic blood pressure. In WT animals, DOCA-salt treatment increased the aortic medial area compared with the non-treated controls. Similarly, Tgfb1 was overexpressed in the aortas of the DOCA-salt treated WT mice compared with the controls. Immunofluorescence staining revealed that fibroblast-specific protein 1 (FSP1) ${ }^{+}-\alpha$ smooth muscle actin ( $\alpha$ SMA) $)^{+}$myofibroblasts exist in the medial area of the WT aortas after DOCA-salt intervention. Importantly, these changes were not observed in the KIf5 ${ }^{\text {Postn }} K O$ animals. In conclusion, the results of this study suggest that the presence of KLF5 in postn-positive cells contributes to the pathogenesis of aortic thickening induced by DOCA-salt hypertension.

Hypertension Research (2016) 39, 764-768; doi:10.1038/hr.2016.65; published online 23 June 2016

Keywords: deoxycorticosterone-acetate salt; Krüppel-like factor 5; periostin; remodeling

\section{INTRODUCTION}

Hypertension is the most common risk factor associated with cardiovascular diseases. Approximately $25 \%$ of the world's adult population have hypertension, and this rate is likely to increase to $29 \%$ by $2025 .{ }^{1}$ Chronic hypertension is known to lead to cardiovascular dysfunction through myocardial hypertrophy and vascular remodeling, ${ }^{2-9}$ however, the pathophysiology of this disease has yet to be elucidated.

Krüppel-like factor 5 (KLF5; also known as BTEB2 and IKLF) is a key mediator of cardiovascular remodeling. ${ }^{10-15}$ KLF5 binds to GC boxes and SP1 sites at a number of gene promoters to regulate their transcription. ${ }^{14,16,17}$ Previously, our group showed that KLF5 overexpression resulted in the proliferation of vascular smooth muscle cells (SMCs). Gene silencing of KLF5 using RNA interference showed marked suppression of cyclin D1 expression and decreased vascular
SMC growth in vitro. ${ }^{14}$ We also demonstrated that overexpression of KLF5 in rats subjected to carotid balloon injury increased neointimal formation and proliferating cell nuclear antigen-positive rates. ${ }^{14}$ Furthermore, we found that angiotensin II infusion suppressed the degrees of arterial-wall thickening, angiogenesis, cardiac hypertrophy and interstitial fibrosis in Klf5-knockout mice. ${ }^{10}$

Periostin (postn) is a well known as a useful marker of noncardiomyocyte lineages, and it is observed on fibroblasts ${ }^{18}$ and SMCs. ${ }^{19}$ Postn has been investigated not only in the cardiovascular system but also in the ischemic brain. ${ }^{20}$ It is not usually expressed in normal physiological conditions, but is induced by tissue injury, contributing to cardiac remodeling. ${ }^{21,22}$ Therefore, it has been suggested that KLF5 in fibroblasts and SMCs has a pivotal role in vascular remodeling. Recently, we generated postn-positive cellspecific Klf5 null mice. ${ }^{15}$ However, the role of KLF5 in fibroblasts

${ }^{1}$ Department of Cardiovascular Medicine, Tokyo Medical and Dental University, Tokyo, Japan; ${ }^{2}$ Department of Advanced Clinical Science and Therapeutics, The University of Tokyo, Tokyo, Japan; ${ }^{3}$ Westmead Millennium Institute for Medical Research, Westmead, New South Wales, Australia; ${ }^{4}$ Department of Cardiovascular Medicine, University of Tokyo, Tokyo, Japan; ${ }^{5}$ Developmental Biology and Neonatal Medicine Program, Herman B Wells Center for Pediatric Research, Indiana University of Medicine, Indianapolis, IN, USA; ${ }^{6}$ Department of Clinical Gene Therapy, Osaka University, Osaka, Japan and ${ }^{7}$ Jichi Medical University, Shimotsuke City, Tochigi, Japan

Correspondence: Dr J Suzuki, Department of Advanced Clinical Science and Therapeutics, Graduate School of Medicine, The University of Tokyo, 7-3-1 Hongo, Bunkyo, Tokyo 113-8655, Japan

E-mail: junichisuzuki-circ@umin.ac.jp

Received 15 December 2015; revised 30 April 2016; accepted 5 May 2016; published online 23 June 2016 
and SMCs on vascular remodeling is still unknown. The aim of this study is to investigate the role of KLF5 in postn-positive cells on vascular remodeling by using DOCA-salt hypertension in mice.

\section{MATERIALS AND METHODS}

\section{Generation of postn-positive cell-specific Klf5-deficient mice}

Mice containing the Klf5 flox allele were crossed with mice expressing Cre recombinase under the control of the Postn promoter to generate mice. ${ }^{15}$ The presence of the Klf5flox/flox and Postn ${ }^{\mathrm{Cre} /-}$ double-transgene was determined using PCR analysis of the genomic DNA from ear tips. The Klf5 deletion of the fibroblasts was validated by western blot analysis of Klf5 $5^{\text {Postn }} \mathrm{KO}$ mice using a KLF5 monoclonal antibody hybridoma supernatant (KM1784). ${ }^{15}$

\section{DOCA pellet implantation}

We used 8-week-old male postn-positive cell-specific Klf5-deficient mice (Klf5 $5^{\text {Postn}}$ KO: Klf $5^{\text {flox/flox; }}$ Postn ${ }^{\text {Crel-l-}}$ ) and wild-type littermate mice (WT: Klf5 $5^{\text {flox/flox; } P o s t n^{-1-}}$ ). The mice were provided access to a standard diet and water. This study was approved by the Animal Care and Use Committee of the Tokyo Medical and Dental University. A DOCA pellet $(25 \mathrm{mg}$, Innovative Research of America, Sarasota, USA) was implanted subcutaneously in the backs of mice under anesthesia as previously described. ${ }^{23}$ Mice receiving a DOCA pellet were given $0.9 \% \mathrm{NaCl}$ to drink. Treatment with DOCA-salt continued for 8 weeks. The control groups, consisting of WT and Klf5 $5^{\text {Postn KO }}$ mice, did not receive DOCA or saline drinking water. Each group consisted of 10-12 mice. Mice were killed after 8 weeks of treatment, and tissue samples were collected for analysis.

\section{Systolic blood pressure}

Systolic blood pressure (SBP) was measured weekly between 1000 and $1200 \mathrm{~h}$ using a tail-cuff system (BP-98A, Softron, Tokyo, Japan) ${ }^{24,25}$ Non-anesthetized mice were prewarmed for $10 \mathrm{~min}$ at $37^{\circ} \mathrm{C}$ in a thermostatically controlled heating cabinet. An average of five individual recordings was taken.

\section{Histopathology}

The aortas were harvested immediately after the mice were killed. Five transverse sections per organ were obtained for each histological examination. The aortic samples were stained with Elastica van Gieson (EvG) staining. ${ }^{26}$ The areas were measured using a computerized analyzer (Scion Image beta 4.0.2: NIST, Gaithersburg, MD, USA).

\section{RNA extraction and real-time PCR}

Total RNA was extracted according to the manufacturer's protocol using TRIsure (Bioline, Tokyo, Japan). Complementary DNA was prepared using a reverse transcriptase-PCR (RT-PCR) kit (QIAGEN, Tokyo, Japan). ${ }^{27}$ PCR was performed using a PCR kit with oligo-primers for transforming growth factor beta 1 (Tgfbl, Mm01178820_m1) and collagenla1 (Colla1, Mm01302043_g1). The sequences of the PCR primers were predesigned and inventoried by TaqMan Gene Expression Assays (Life Technologies Japan, Tokyo, Japan). The results were obtained from three independent experiments (five samples in each group).

\section{Immunofluorescence staining}

Immunohistochemistry was performed to examine CD11b (1561-01, SouthernBiotech), $\alpha$-smooth muscle actin ( $\alpha$ SMA-FITC: F3777, Sigma-Aldrich, St Louis, MO, USA) and fibroblast-specific protein 1 (FSP1; also known as S100A4, ab27957, Abcam, Cambridge, UK) expression in the aorta. The sections were incubated overnight at $4{ }^{\circ} \mathrm{C}$ with primary antibodies and washed using PBST. Secondary antibodies were then applied for $60 \mathrm{~min}$ at room temperature. After washing in PBST, the sections were counterstained with DAPI (CS-201-06, InnoGenex, San Ramon, CA, USA).

\section{Statistics}

Statistical analysis was performed using SPSS Base System 14.0J for Windows (IBM Japan, Tokyo, Japan). All the data were expressed as the mean \pm s.e.; statistical comparisons were performed using a one-way ANOVA with Tukey
HSD post hoc test or a one-way ANOVA repeated measures with Sidak's multiple comparison test. $P<0.05$ was considered statistically significant.

\section{RESULTS}

\section{Blood pressure}

Figure 1 shows the SBP for the four groups of mice over an 8-week period. Despite genotype differences, the control WT and Klf5 $5^{\text {Postn }} \mathrm{KO}$ mice had comparable SBPs. Similarly, DOCA-salt treatment increased the SBP of the WT and Klf5 $5^{\text {Postn }} \mathrm{KO}$ mice. There was no difference in the SBP of the WT-DOCA and Klf5 $5^{\text {Postn }} \mathrm{KO}-\mathrm{DOCA}$ mice.

\section{Histopathology of the aortas}

It is known that DOCA-salt hypertension increases aortic wall thickness. $^{6}$ Thus, we examined whether DOCA-salt treatment increased the aortic medial area in the Klf5 ${ }^{\text {Postn }} \mathrm{KO}$ mice (Figures 2a and $b$ ). In the control groups, there was no significant difference in the aortic wall medial area between the WT and Klf5 $5^{\text {Postn }} \mathrm{KO}$ mice. DOCA-salt treatment significantly increased the aortic wall medial area in the WT animals. However, the treatment did not alter the aortic wall medial area in the Klf5 ${ }^{\text {Postn }} \mathrm{KO}$ animals. This result indicates that the Klf5 $5^{\text {Postn }} \mathrm{KO}$ mice do not have histopathological changes after an 8-week DOCA-salt intervention.

\section{mRNA expression in the aorta}

We examined whether DOCA-salt intervention alters gene expression in the aorta (Figure 2c). In the aortas of the control group, there was no significant difference in Tgfb1 mRNA levels between the WT and Klf $5^{\text {Postn }} \mathrm{KO}$ mice. DOCA-salt treatment significantly increased $T g f b 1$ mRNA levels in the WT animals $(P<0.001)$. However, the treatment did not alter Tgfbl mRNA levels in the Klf5 ${ }^{\text {Postn }} \mathrm{KO}$ animals. There was no significant difference in the mRNA levels of Collal mRNA of the


tions indicate that DOCA-salt treatment increases $T g f b 1$ in the aortas of the WT mice, but not in the Klf5 $5^{\text {Postn }} \mathrm{KO}$ mice.

\section{Immunofluorescence staining}

Figure 3 shows representative immunofluorescence staining. CD11b lymphocyte infiltration was observed only in the tunica adventitia. Next, immunofluorescence staining showed that $\alpha \mathrm{SMA}$ was equally expressed in the aortic media of all groups (Figure $3 \mathrm{~b}$ ). In contrast,

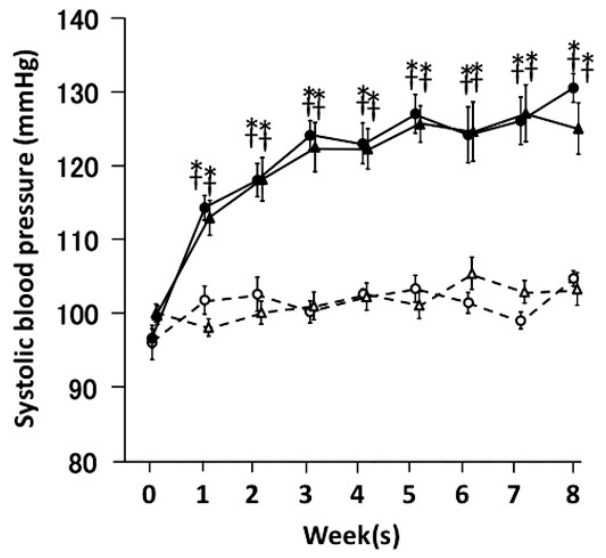

Figure 1 Systolic blood pressure during the 8-week DOCA-salt treatment period. Open circle, WT-control mice $(n=10)$; open triangle, KIf5PostnKOcontrol mice $(n=12)$; solid circle, WT-DOCA-salt mice $(n=11)$; solid triangle, KIf5 ${ }^{\text {Postn } K O-D O C A-s a l t ~ m i c e ~}(n=10)$. Values are the mean \pm s.e. ${ }^{*} P<0.05$ vs. WT-Cont. ${ }^{\dagger} P<0.05$ vs. Klf5 ${ }^{\text {Cre/--Cont. }}$ 
a

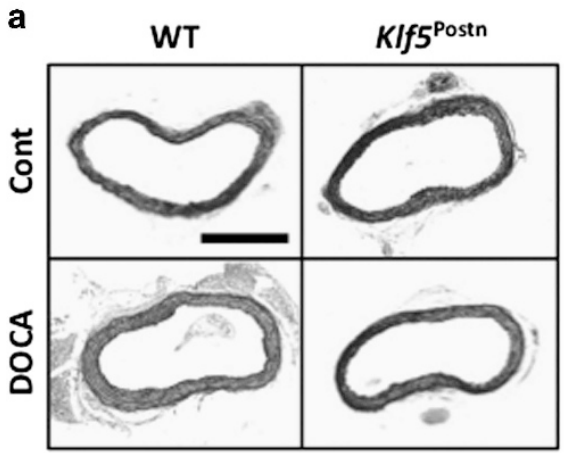

C

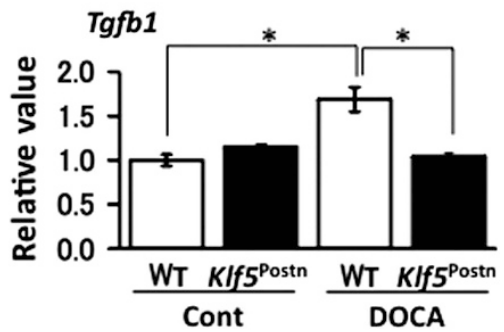

b

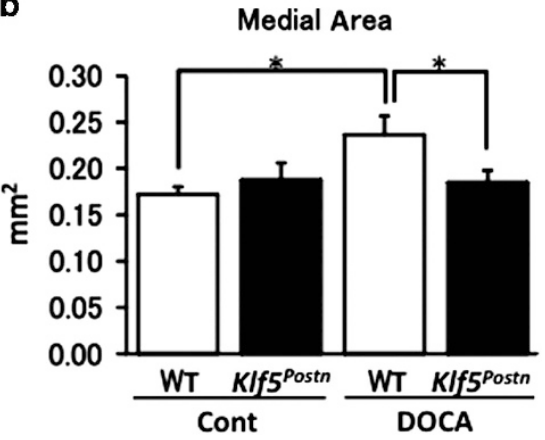

Col1a1

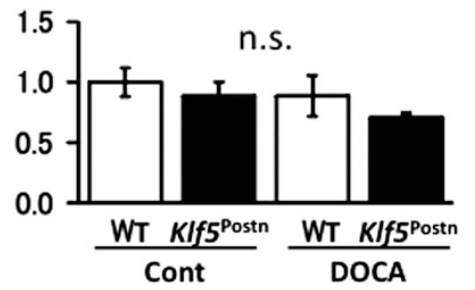

Figure 2 Myofibroblasts localize in the thickened aortic media after 8 weeks of DOCA-salt treatment. (a) Representative EvG staining of the aorta ( $\times 100)$. Bar, $500 \mu \mathrm{m}$. (b) Aortic medial wall area. $n=10$ per group. ${ }^{*} P<0.05$. (c) mRNA expression of Tgfbl and Colla1 in the aorta. $n=5$ per group. Values are the mean \pm s.e. ${ }^{*} P<0.05$.

FSP1 was observed in the aortic media of the WT-DOCA mice

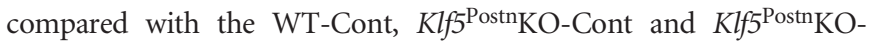
DOCA mice. These results show that FSP1 cells are co-expressed with $\alpha \mathrm{SMA}$ in the aortic media.

\section{DISCUSSION}

The present study revealed that only the aortic medial area of WT mice increased, while DOCA-salt treatment similarly increased the SBP of the WT and Klf5 $5^{\text {Postn }} \mathrm{KO}$ mice. Furthermore, our data revealed that many $\mathrm{FSP}^{+} \alpha \mathrm{SMA}^{+}$myofibroblasts are found in the thickened aortic media during DOCA-salt treatment. Additionally, in contrast to WT murine aortas, Klf5 $5^{\text {Postn }} \mathrm{KO}$ mice exhibited lower FSP1 protein expression induction by DOCA-salt treatment. These results suggest that KLF5 participates in myofibroblast conversion and/or migration to the aortic media during DOCA-salt induced hypertension.

TGF $\beta 1$ expression is known to be induced by DOCA treatment and by endothelin-1. ${ }^{28,29}$ Consistent with these previous observations, DOCA-salt hypertension is also associated with endothelin-1 dependence. ${ }^{30-33}$ An earlier study demonstrated that endothelin-1 also directly upregulates KLF5 expression. ${ }^{13}$ Additionally, we have reported that $T g f b 1$ expression is significantly lower in the hearts of systemic Klf5-knockout mice than in WT mice following angiotensin II infusion, suggesting that TGF $\beta 1$ lies downstream of KLF5. ${ }^{10}$ Therefore, DOCA-salt treatment enhances the expression of KLF5 via an endothelin-1 mechanism within myofibroblasts; KLF5 in myofibroblasts might be involved in aortic thickening via a Tgfbl expression pathway.

Our group previously showed that pressure overload using transverse aortic constriction suppressed the degree of cardiac hypertrophy and interstitial fibrosis in Klf5-knockout mice. ${ }^{15}$ In this study, we used a DOCA-salt induced hypertension model in mice; however, there was no difference in the heart weights of WT and Klf5PostnKO mice (data not shown). A reason for the differences of these studies may depend on the pressure intensities. Indeed, systolic blood pressure was approximately $130 \mathrm{~mm} \mathrm{Hg}$ in the present study. Although these studies used different models (DOCA-salt or transverse aortic constriction), the results suggest that KLF5 is necessary for pressure load-induced cardiovascular remodeling.

Myofibroblasts are involved in wound healing and tissue repair. ${ }^{34}$ Previous studies demonstrate that most myofibroblasts express $\alpha \mathrm{SMA}$ and that the expression of $\alpha \mathrm{SMA}$ and collagen type $\mathrm{I}$ in these cells is regulated coordinately by TGF $\beta 1 .{ }^{35}$ However, the results of the present study show that DOCA-induced aortas and myofibroblasts did not increase Collal gene expression. This result suggests that DOCAtreated myofibroblasts tend to be the contraction type rather than the extracellular-matrix producing type.

A study showed that transient receptor potential melastatin 7 promotes vascular adventitial remodeling in transverse aortic constriction rats, ${ }^{36}$ while the present study suggests that KLF5 involves the aortic medial wall. Zhang et al. demonstrated that KLF5 expression increased with the phenotypic switching of vascular SMCs from a contractile to a proliferative state in clinical aortic wall samples of atherosclerotic aortas. They also showed significantly increased KLF5 gene and protein expression in cultured vascular SMCs from atherosclerotic donors. These results suggest that a more proliferative state of vascular SMCs from patients with atherosclerosis may be associated with a higher expression of KLF5. ${ }^{37}$ Endothelin-1 is known to have an especially prominent role in DOCA-salt hypertension. ${ }^{38}$ One important effect of this situation is to increase total peripheral resistance by contracting the arteries and arterioles. ${ }^{39}$ Prepro-endothelin-1 mRNA expression and immunoreactive endothelin-1 content of the aorta are increased in DOCA-salt rats, ${ }^{40-42}$ suggesting that one mechanism of endothelin-1-induced arterial constriction in hypertension is to increase the levels of peptide around the arterial smooth muscles. However, there is currently no direct evidence regarding endothelin-1 regulation of aortic SMC proliferation via KLF5. Recently, Courboulin et al. ${ }^{43}$ demonstrated that endothelin-1 triggered KLF5 activation in pulmonary artery SMCs. They showed that the pulmonary artery 
a

$\begin{array}{lclc}\text { WT- } & \text { KIf } 5^{\text {PostnKO }} & \text { WT- } & \text { KIf } 5^{\text {PostnKO }} \\ \text { Cont } & - \text { Cont } & \text { DOCA } & \text {-DOCA }\end{array}$

HE

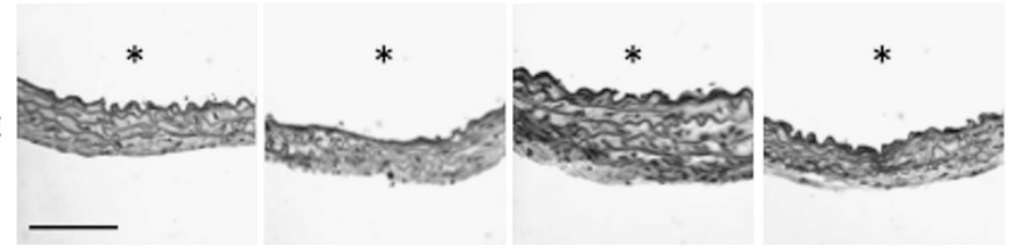

CD11b
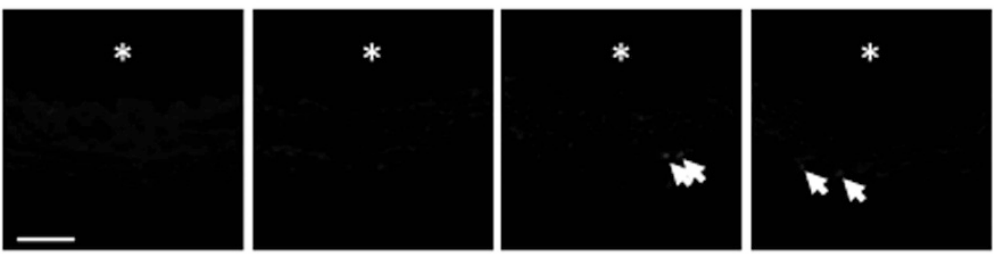

b
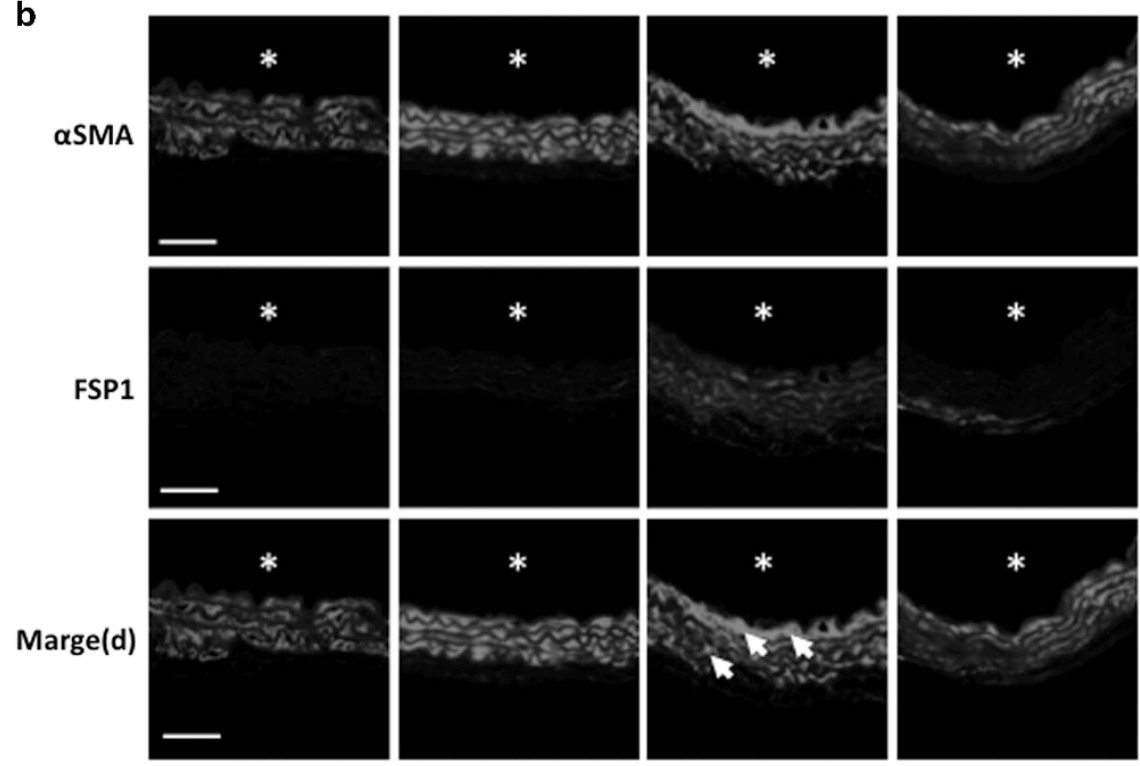

Figure 3 DOCA-salt treatment induced myofibroblast transition in the aortic media of WT, but not Klf5 Postn KO mice. (a) Representative EvG (magnification, $\times 400$; scale bar, $100 \mu \mathrm{m}$ ) and immunofluorescence staining (magnification, $\times 600$; scale bar, $50 \mu \mathrm{m}$ ) of the aorta. Arrows point to CD11 $\mathrm{b}^{+}$cells. (b) Immunofluorescence staining of the aorta revealed an increased number of $\alpha S M A^{+}$FSP1 ${ }^{+}$cells in WT-DOCA-salt mice. Scale, $\times 600 ;$ bar, $50 \mu m$. The asterisks indicate the lumen. A full color version of this figure is available at the Hypertension Research journal online.

SMCs with increased KLF5 were implicated in the pro-proliferative phenotype. Thus, the DOCA-endothelin-1-KLF5 pathway may be critical in this pathophysiology. Because arterial remodeling includes different pathological phenomena, further investigation is needed to clarify the detailed mechanism.

In conclusion, the results of this study suggest that the presence of KLF5 in postn-positive cells contributes to the pathogenesis of the aortic thickening induced by DOCA-salt treatment hypertension.

\section{CONFLICT OF INTEREST}

The authors declare no conflict of interest.

\section{ACKNOWLEDGEMENTS}

We would like to thank Ms Noriko Tamura and Ms Yasuko Matsuda for their excellent technical assistance. This study was supported by the Japan Society for the Promotion of Science (JSPS) through its 'Funding Program for WorldLeading Innovative R\&D on Science and Technology (FIRST Program)'.
1 Mittal BV, Singh AK. Hypertension in the developing world: challenges and opportunities. Am J Kidney Dis 2010; 55: 590-598.

2 Hagiwara M, Bledsoe G, Yang ZR, Smith RS Jr, Chao L, Chao J. Intermedin ameliorates vascular and renal injury by inhibition of oxidative stress. Am J Physiol Renal Physiol 2008; 295: F1735-F1743.

3 Wolinsky $\mathrm{H}$. Long-term effects of hypertension on the rat aortic wall and their relation to concurrent aging changes. Morphological and chemical studies. Circ Res 1972; 30: 301-309.

4 Levy BI, Michel JB, Salzmann JL, Azizi M, Poitevin P, Safar M, Camilleri JP. Effects of chronic inhibition of converting enzyme on mechanical and structural properties of arteries in rat renovascular hypertension. Circ Res 1988; 63: 227-239.

5 Simko F, Matuskova J, Luptak I, Krajcirovicova K, Kucharska J, Gvozdjakova A, Babal P, Pechanova O. Effect of simvastatin on remodeling of the left ventricle and aorta in L-NAME-induced hypertension. Life Sci 2004; 74: 1211-1224.

6 Watts SW, Rondelli C, Thakali K, Li X, Uhal B, Pervaiz MH, Watson RE, Fink GD. Morphological and biochemical characterization of remodeling in aorta and vena cava of DOCA-salt hypertensive rats. Am J Physiol Heart Circ Physiol 2007; 292: H2438-H2448.

7 Nakashima T, Umemoto S, Yoshimura K, Matsuda S, Itoh S, Murata T, Fukai T, Matsuzaki M. TLR4 is a critical regulator of angiotensin II-induced vascular remodeling: the roles of extracellular SOD and NADPH oxidase. Hypertens Res 2015; 38: 649-655.

8 Letavernier E, Perez J, Bellocq A, Mesnard L, de Castro Keller A, Haymann JP, Baud L. Targeting the calpain/calpastatin system as a new strategy to prevent cardiovascular remodeling in angiotensin II-induced hypertension. Circ Res 2008; 102: 720-728. 
9 Yu C, Chen J, Guan W, Han Y, Wang WE, Wang X, Wang H, Jose PA, Zeng C. Activation of the D4 dopamine receptor attenuates proliferation and migration of vascular smooth muscle cells through downregulation of AT1a receptor expression. Hypertens Res 2015; 38: 588-596.

10 Shindo T, Manabe I, Fukushima Y, Tobe K, Aizawa K, Miyamoto S, Kawai-Kowase K, Moriyama N, Imai $Y$, Kawakami $H$, Nishimatsu $H$, Ishikawa $T$, Suzuki T, Morita $H$, Maemura K, Sata M, Hirata Y, Komukai M, Kagechika H, Kadowaki T, Kurabayashi M, Nagai R. Kruppel-like zinc-finger transcription factor KLF5/BTEB2 is a target for angiotensin II signaling and an essential regulator of cardiovascular remodeling. Nat Med 2002; 8: 856-863.

11 Nagai R, Shindo T, Manabe I, Suzuki T, Kurabayashi M. KLF5/BTEB2, a Kruppel-like zinc-finger type transcription factor, mediates both smooth muscle cell activation and cardiac hypertrophy. Adv Exp Med Biol 2003; 538: 57-65 discussion 66.

12 Fujiu K, Manabe I, Ishihara A, Oishi Y, Iwata H, Nishimura G, Shindo T, Maemura K, Kagechika H, Shudo K, Nagai R. Synthetic retinoid Am80 suppresses smooth muscle phenotypic modulation and in-stent neointima formation by inhibiting KLF5. Circ Res 2005; 97: 1132-1141.

13 Cullingford TE, Butler MJ, Marshall AK, Tham el L, Sugden PH, Clerk A. Differential regulation of Kruppel-like factor family transcription factor expression in neonatal rat cardiac myocytes: effects of endothelin-1, oxidative stress and cytokines. Biochim Biophys Acta 2008; 1783: 1229-1236.

14 Suzuki T, Sawaki D, Aizawa K, Munemasa Y, Matsumura T, Ishida J, Nagai R. Kruppellike factor 5 shows proliferation-specific roles in vascular remodeling, direct stimulation of cell growth, and inhibition of apoptosis. J Biol Chem 2009; 284: 9549-9557.

15 Takeda N, Manabe I, Uchino Y, Eguchi K, Matsumoto S, Nishimura S, Shindo T, Sano M, Otsu K, Snider P, Conway SJ, Nagai R. Cardiac fibroblasts are essential for the adaptive response of the murine heart to pressure overload. J Clin Invest 2010; 120: 254-265.

16 Sogawa K, Imataka H, Yamasaki Y, Kusume H, Abe H, Fujii-Kuriyama Y. cDNA cloning and transcriptional properties of a novel GC box-binding protein, BTEB2. Nucleic Acids Res 1993; 21: 1527-1532.

17 Dong JT, Chen C. Essential role of KLF5 transcription factor in cell proliferation and differentiation and its implications for human diseases. Cell Mol Life Sci 2009; 66: 2691-2706.

18 Snider P, Standley KN, Wang J, Azhar M, Doetschman T, Conway SJ. Origin of cardiac fibroblasts and the role of periostin. Circ Res 2009; 105: 934-947.

19 Li G, Jin R, Norris RA, Zhang L, Yu S, Wu F, Markwald RR, Nanda A, Conway SJ, Smyth SS, Granger DN. Periostin mediates vascular smooth muscle cell migration through the integrins alphavbeta3 and alphavbeta5 and focal adhesion kinase (FAK) pathway. Atherosclerosis 2010; 208: 358-365.

20 Shimamura M, Taniyama Y, Nakagami H, Katsuragi N, Wakayama K, Koriyama $\mathrm{H}$, Kurinami H, Tenma A, Tomioka H, Morishita R. Long-term expression of periostin during the chronic stage of ischemic stroke in mice. Hypertens Res 2014; 37: 494-499.

21 Oka T, Xu J, Kaiser RA, Melendez J, Hambleton M, Sargent MA, Lorts A, Brunskill EW, Dorn GW 2nd, Conway SJ, Aronow BJ, Robbins J, Molkentin JD. Genetic manipulation of periostin expression reveals a role in cardiac hypertrophy and ventricular remodeling. Circ Res 2007; 101: 313-321.

22 Conway SJ, Molkentin JD. Periostin as a heterofunctional regulator of cardiac development and disease. Curr Genomics 2008; 9: 548-555.

23 Mohammed SF, Ohtani T, Korinek J, Lam CS, Larsen K, Simari RD, Valencik ML, Burnett JC Jr, Redfield MM. Mineralocorticoid accelerates transition to heart failure with preserved ejection fraction via 'nongenomic effects'. Circulation 2010; 122: 370-378.

24 Suzuki J, Ogawa M, Futamatsu H, Kosuge H, Sagesaka YM, Isobe M. Tea catechins improve left ventricular dysfunction, suppress myocardial inflammation and fibrosis, and alter cytokine expression in rat autoimmune myocarditis. Eur J Heart Fail 2007; 9: 152-159.

25 Liao Y, Ishikura F, Beppu S, Asakura M, Takashima S, Asanuma H, Sanada S, Kim J, Ogita H, Kuzuya T, Node K, Kitakaze M, Hori M. Echocardiographic assessment of LV hypertrophy and function in aortic-banded mice: necropsy validation. Am J Physiol Heart Circ Physiol 2002; 282: H1703-H1708.

26 Aguero J, Ishikawa K, Hadri L, Santos-Gallego C, Fish K, Hammoudi N, Chaanine A, Torquato S, Naim C, Ibanez B, Pereda D, Garcia-Alvarez A, Fuster V, Sengupta PP, Leopold JA, Hajiar RJ. Characterization of right ventricular remodeling and failure in a chronic pulmonary hypertension model. Am J Physiol Heart Circ Physiol 2014; 307: H1204-H1215.

27 Ashigaki N, Suzuki J, Ogawa M, Watanabe R, Aoyama N, Kobayashi N, Hanatani T, Sekinishi A, Zempo H, Tada Y, Takamura C, Wakayama K, Hirata Y, Nagai R, Izumi Y, Isobe M. Periodontal bacteria aggravate experimental autoimmune myocarditis in mice. Am J Physiol Heart Circ Physiol 2013; 304: H740-H748.

28 Sarzani R, Brecher P, Chobanian AV. Growth factor expression in aorta of normotensive and hypertensive rats. J Clin Invest 1989; 83: 1404-1408.

29 Ammarguellat F, Larouche I, Schiffrin EL. Myocardial fibrosis in DOCA-salt hypertensive rats: effect of endothelin ET(A) receptor antagonism. Circulation 2001; 103: 319-324.

30 Di Zhang A, Nguyen Dinh Cat A, Soukaseum C, Escoubet B, Cherfa A, Messaoudi S, Delcayre C, Samuel JL, Jaisser F. Cross-talk between mineralocorticoid and angiotensin II signaling for cardiac remodeling. Hypertension 2008; 52: 1060-1067.

$31 \mathrm{Li} \mathrm{L}$, Watts SW, Banes AK, Galligan JJ, Fink GD, Chen AF. NADPH oxidase-derived superoxide augments endothelin-1-induced venoconstriction in mineralocorticoid hypertension. Hypertension 2003; 42: 316-321.

32 Karam H, Heudes D, Hess P, Gonzales MF, Loffler BM, Clozel M, Clozel JP. Respective role of humoral factors and blood pressure in cardiac remodeling of DOCA hypertensive rats. Cardiovasc Res 1996; 31: 287-295.

33 Callera GE, Touyz RM, Teixeira SA, Muscara MN, Carvalho MH, Fortes ZB, Nigro D, Schiffrin EL, Tostes RC. ETA receptor blockade decreases vascular superoxide generation in DOCA-salt hypertension. Hypertension 2003; 42: 811-817.

34 Desmouliere A. Factors influencing myofibroblast differentiation during wound healing and fibrosis. Cell Biol Int 1995; 19: 471-476.

35 Tomasek JJ, Gabbiani G, Hinz B, Chaponnier C, Brown RA. Myofibroblasts and mechano-regulation of connective tissue remodelling. Nat Rev Mol Cell Biol 2002; 3: 349-363.

$36 \mathrm{Li} \mathrm{Y,} \mathrm{Jiang} \mathrm{H,} \mathrm{Ruan} \mathrm{C,} \mathrm{Zhong} \mathrm{J,} \mathrm{Gao} \mathrm{P,} \mathrm{Zhu} \mathrm{D,} \mathrm{Niu} \mathrm{W,} \mathrm{Guo} \mathrm{S.} \mathrm{The} \mathrm{interaction} \mathrm{of}$ transient receptor potential melastatin 7 with macrophages promotes vascular adventitial remodeling in transverse aortic constriction rats. Hypertens Res 2014; 37: 35-42.

37 Zhang YN, Xie BD, Sun L, Chen W, Jiang SL, Liu W, Bian F, Tian H, Li RK. Phenotypic switching of vascular smooth muscle cells in the 'normal region' of aorta from atherosclerosis patients is regulated by miR-145. J Cell Mol Med 2016; 20 : 1049-1061.

38 Schiffrin EL. Endothelin: potential role in hypertension and vascular hypertrophy. Hypertension 1995; 25: 1135-1145.

39 Day R, Lariviere R, Schiffrin EL. In situ hybridization shows increased endothelin-1 mRNA levels in endothelial cells of blood vessels of deoxycorticosterone acetate-salt hypertensive rats. Am J Hypertens 1995; 8: 294-300.

40 Lariviere R, Day R, Schiffrin EL. Increased expression of endothelin-1 gene in blood vessels of deoxycorticosterone acetate-salt hypertensive rats. Hypertension 1993; 21 (6 Pt 2): 916-920.

41 Lariviere R, Thibault G, Schiffrin EL. Increased endothelin-1 content in blood vessels of deoxycorticosterone acetate-salt hypertensive but not in spontaneously hypertensive rats. Hypertension 1993; 21: 294-300.

42 Schiffrin EL, Lariviere R, Li JS, Sventek P. Enhanced expression of the endothelin-1 gene in blood vessels of DOCA-salt hypertensive rats correlation with vascular structure. J Vasc Res 1996; 33: 235-248.

43 Courboulin A, Tremblay VL, Barrier M, Meloche J, Jacob MH, Chapolard M, Bisserier M, Paulin R, Lambert C, Provencher S, Bonnet S. Krüppel-like factor 5 contributes to pulmonary artery smooth muscle proliferation and resistance to apoptosis in human pulmonary arterial hypertension. Respir Res 2011; 12: 128. 